\title{
Supplementation effects of Calotropis procera dried leaves on the growth performance of sheep in dry season in Burkina Faso
}

\begin{abstract}
This study evaluated the effects of two levels of supplementation of dried leaves of C. Procera on sorghum straw ingestion and weight evolution of sheep Mossi breed in Burkina Faso. To this end, 15 sheep Mossi breed weighing an average of $13.3 \pm 3.2 \mathrm{~kg}$ were divided into three groups of five (5) animals and subjected to three diets during 35 days in dry season (April-May). Group A (control) received finely chopped sorghum straw, while groups B and C received $100 \mathrm{~g}$ and $200 \mathrm{~g}$ of C. Procera dried leaves in addition to the sorghum straw. The forages distributed contained $2 \%$ of raw salt. Mean ingestion rates for sorghum straw were $55.44 \%, 61.39 \%$ and $60.58 \%$ for lots A, B and $\mathrm{C}$ respectively. The average daily gains (ADG) obtained were $5.7 \mathrm{~g}$ and $1.1 \mathrm{~g}$ for the animals of groups B and C, respectively, against $-18.2 \mathrm{~g}$ for those of group A. These results suggest the possibility of valorizing C. Procera dried leaves in the rations of sheep in farming area as strategic supplementation to ensure better production in the dry season.
\end{abstract}

Keywords: calotropis procera, sheep, nutritional supplementation, weight gain
Volume 6 Issue I - 2017

\author{
Kabore Adama,' Kondombo Clarisse P,' \\ Gnanda B Isidore,' Kologo Issouf, ${ }^{2}$ Konate \\ Almamy,' Yougbare Bernadette, 'Traore \\ Amadou,' Tamboura Hamidou H,' Belem AM \\ Gaston $^{3}$ \\ 'Institut de l'Environnement et de Recherches Agricoles \\ (INERA), Burkina Faso \\ ${ }^{2}$ Ministère des ressources Animales et Halieutiques, Burkina \\ Faso \\ ${ }^{3}$ Institut de Développement Rural, Université Nazi Boni de \\ Bobo-Dioulasso, Burkina Faso
}

Correspondence: Kabore Adama, Institut de l'Environnement et de Recherches Agricoles (INERA), 04 BP 8645 Ouagadougou 04, Ouagadougou, Burkina Faso, Tel +226 702810 98, Email adel_bf@yahoo.fr

Received: September 03, 2017 | Published: October 16, 2017

\section{Introduction}

Burkina Faso is an agro-pastoral country where livestock is practiced on all these forms. Agriculture and livestock occupy over $90 \%$ of the working population and form the basis of the national economy. The latter contributes more than $12 \%$ to the Gross Domestic Product (GDP) and $40 \%$ of the country's export earnings. ${ }^{1}$ The national herd is important and diverse with an estimated ruminant population of 9091000 cattle, 9278000 sheep and 13891000 goats. $^{2}$ Livestock activities are carried out by more than $80 \%$ of households who derive all or part of their income. ${ }^{3}$ Cattle are the savings account of the family business, while small ruminants constitute the current account that allows smallholder farmers to meet their daily needs. ${ }^{4}$ This current account is used in health, education and traditional practices. ${ }^{5}$ However, ruminant livestock production in the country is generally confronted with climatic hazards, overgrazing, population expansion and occupation of pasture areas aggravated by bush fires. ${ }^{6}$ This situation is less predicted in the rainy season with natural grazing in quantity and quality. However, in the hot dry season, existing pasture does not represent nutritional values anymore, while it is rich in ligneous forages in some localities. These perennial woods could therefore be a solution to the feeding problem of ruminants in this lean season where animals lose a lot of weight in general and their zootechnical value in particular. Indeed, some invasive woody trees in Burkina Faso have interesting nutritive values for animals and could be used to improve qualitatively low-season dry season rations such as sorghum straw. The present study was conducted to study the nutritive value of dried leaves of $C$. Procera in order to determine its optimum level of incorporation into the ration of sheep in the dry season to improve their growth performance.

\section{Materials and methods}

\section{Study site}

Our study was conducted at the Saria experimental station $\left(12^{\circ} 16^{\prime}\right.$ north latitude and $2^{\circ} 09^{\prime}$ west longitude and $300 \mathrm{~m}$ altitude). The climate of the zone is of the Northern Sudanian type ${ }^{7}$ where there are two great seasons: the rainy season from June to October and the dry season, from November to May. The average annual precipitation is about $800 \mathrm{~mm}$. The vegetation of Saria is of the Sudanian type and characterized by the presence of an annual grassland savanna, with trees and shrubs. The most frequently encountered trees are Parkiabiglobosa, Buttyrospermunsp, Faidherbiaalbida, Adansoniadigitata, Guierasenegalensis. The herbaceous stratum is mainly represented by species such as Pennisetumsp, Antropogonsp, Loudetiatogoensis L. and Schoenefeldiagracilis.

\section{Vegetal material}

The dry leaves of $C$. Procera were used to carry out the experimental test. The leaves of the plant were harvested from February to March 2016. The drying was done in the shade sheltered from the sun and dust with a reversal of two to three times a day. Depending on the time of harvest, drying lasted 96hours on average. To facilitate the consumption of the prepared forage, it has been finely chopped. This product was stored in plastic bags for distribution to animals.

Sorghum straw of the Sariaso 16 variety (SCHV 186) was also used to conduct the test. Sariaso 16 is an improved variety belonging to the C. Audatum botanical breed co-developed in Burkina Faso by INERA and CIRAD in 2008. The plant has a height varying from 
205 to $230 \mathrm{~cm}$ with the broad leaves. It is a dual-purpose plant with good forage value of straw when residues are harvested early. Straw drying was done according to peasant practices (in the field under the sun) which depreciate the forage quality of the product. The straw was finely chopped to facilitate apprehension and avoid wastage by animals.

\section{Animals and experimental design}

Fifteen sheep Mossi breed from the sheepfold of Saria experimental station and weighing an average of $13.3 \pm 3.2 \mathrm{~kg}$, were used for the experiment between April and May during hot dry season. These animals were divided into three groups (A, B and C) of five animals and homogeneous weight $(\mathrm{P}>0.05)$.

Feeding test was carried out on the three groups of sheep for 35 days by applying the following design:

A. Group A (control): Sorghum straw finely chopped and and containing $2 \%$ salt

B. Group B: Sorghum straw finely chopped and containing $2 \%$ sal$\mathrm{t}+100 \mathrm{~g}$ dry leaves of C. Procera;

C. Group C: Sorghum straw finely chopped and containing $2 \%$ sal$\mathrm{t}+200 \mathrm{~g}$ dry leaves of C. Procera

These quantities of dry forage distributed were determined during the adaptation phase (two week). Animals of three groups were carried out according to the practice of rural farmer's doing agropastoral system which predominate in the study area. Every day, all animals were taken to the pasture every day from $8 \mathrm{~h}$ AM to $2 \mathrm{~h}$ PM. They received the sorghum straw every morning at $7 \mathrm{am}$ and in the evening at $2 \mathrm{pm}$ throughout the experiment. C. Procera dried leaves were fed in the evening at $5 \mathrm{~h} \mathrm{pm}$. Each morning, all refusals of each group were collected and weighed before serving again. All animals in both groups had Ad libitum access to water.

The following parameters were measured:

i. Dry matter (DM) values of dry forage (C. procera and sorghum straw) were determined using the AOAC method. ${ }^{8}$ From this value, those of mineral (MM), organic (MO), crude protein $(\mathrm{CP})$ and crude fiber $(\mathrm{CF})$ were determined;

ii. Voluntary intake of the forage distributed. For this purpose, daily weighing of the quantities of $C$. Procera and sorghum straw distributed and the quantities of refusals were used to determine the daily voluntary intake as follows:

$$
\mathrm{IV}=\mathrm{QD}-\mathrm{QR}
$$

Where, IV=Voluntary Intake, QD=Distributed Quantity, $\mathrm{QR}=$ Quantity Refused

iii. Weight growth of the animals of each group from individual weekly weighings made on dates $\mathrm{D}_{0}, \mathrm{D}_{7}, \mathrm{D}_{14}, \mathrm{D}_{21}, \mathrm{D}_{28}$ and $\mathrm{D}_{35}$ to establish the weekly average by group.

\section{Statistical analysis}

Data collected were used to calculate the means of each measured parameters before being subjected to a one-way variance analysis to discriminate their effects. The Tukey-Kramer test at 5\% significance was used to compare the means obtained with the Costat software (version 6.20.4).

\section{Results}

\section{Chemical composition}

Table 1 gives the Chemical composition contents C. Procera dried leaves of and the sorghum straw distributed during the study. The dried leaves of $C$. Procera contain high dry matter (DM=93, 20\%) and mineral $(\mathrm{MM}=17.02 \% \mathrm{DM})$ contents, good crude protein $(\mathrm{CP})$ and low crude fiber $(\mathrm{CF})$ content at the harvest stage. Sorghum straw has a low level of $\mathrm{CP}$ and a high value of crude fiber, the main source of energy for ruminants.

\section{Animal feed consumption}

Table 2 presents the cconsumption level of distributed fodder. Average ingestion rates of C. Procera were $100 \%$ and $98.68 \%$ in groups $\mathrm{B}$ and $\mathrm{C}$ respectively. The dry matter quantities of $C$. Procera leaves ingested in group $\mathrm{C}$ represent approximately the double of the quantities ingested in group B. In the three experimental groups, the animals did not consume all the sorghum straw and the ingestion rates varied significantly $(\mathrm{P}<0.05)$. The consumption of sorghum straw in the supplemented groups was higher than that in the control group, where the mean ingestion rate was $55.44 \%$. In the groups supplemented, no significant differences $(\mathrm{P}>0.05)$ were noted between group $\mathrm{B}$ $(61.39 \%)$ and group $\mathrm{C}(60.58 \%)$. In addition, Figure 1 indicates that consumption of $100 \mathrm{~g}$ dry leaves of C. Procera (per animal per day) induces a high intake of sorghum straw in the supplemented groups.

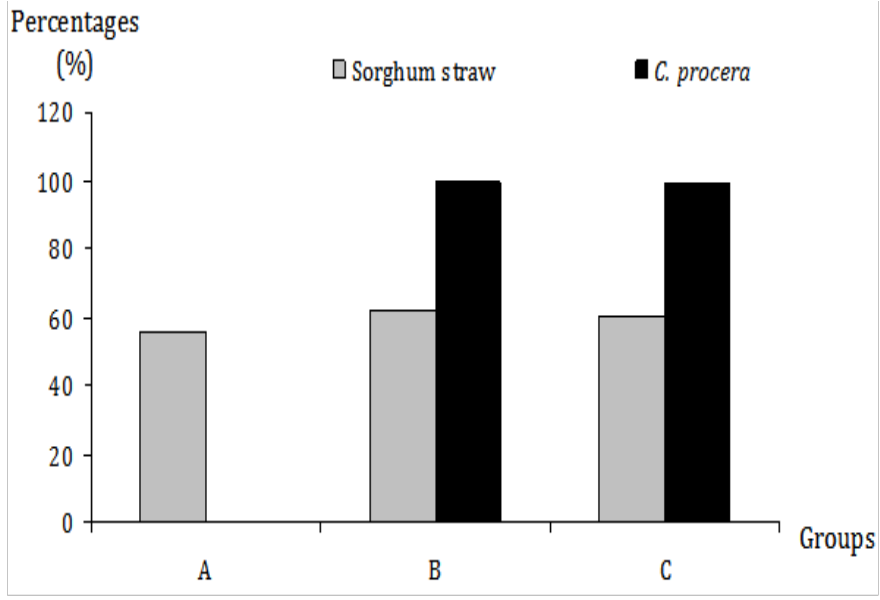

Figure I Influence of $C$. Procera dry leaves on the intake rate of sorghum straw during the experiment.

\section{Effect on weight performance}

The body weight and the Average Daily Weight Gain (ADWG) of sheep in the three groups are shown in Table 3. Mean of animal body weight in the control group increased from $13.4 \pm 2.0 \mathrm{~kg}$ to $12.8 \pm 2.0 \mathrm{~kg}$ while those of the supplemented groups increased from $13.36 \pm 3.2 \mathrm{~kg}$ to $13.56 \pm 3.2 \mathrm{~kg}$ for group B and from $13.36 \pm 3.1 \mathrm{~kg}$ to $13.4 \pm 3 \mathrm{~kg}$ for the group C. However, the comparison of sheep body weight presented no significant difference $(\mathrm{P}>0.05)$ between the three groups. But the ADWG obtained by the control group animals $(-18.2 \pm 7.4 \mathrm{~g})$ were statistically lower $(\mathrm{P}<0.05)$ than those of the supplemented groups. However, the ADWG between the supplemental groups $(\mathrm{B}=5.7 \pm 8.0 \mathrm{~g}$ and $\mathrm{C}=1.1 \pm 10.9 \mathrm{~g})$ did not show a significant difference $(\mathrm{P}>0.05)$ (Table 3). 
Table I Chemical composition of C. Procera dried leaves and sorghum straw of the study

\begin{tabular}{llllll}
\hline \multirow{2}{*}{ Feed } & DM (\%) & \multicolumn{2}{c}{$\%$ DM } & & \\
\cline { 3 - 6 } & & MM & CP & MO & CF \\
\hline C. procera & 93,20 & 17.02 & 19.07 & 82.98 & 23.44 \\
Sorghum straw & 94,14 & nd & 3.9 & 91,4 & 34,4
\end{tabular}

DM, dry matter; MM, mineral matter; $\mathrm{CP}$, crude protein; $\mathrm{MO}$, organic matter; CF, crude fiber

Table 2 Intake level of fodder distributed during the experiment

\begin{tabular}{lllll}
\hline \multirow{2}{*}{ Groups } & $\begin{array}{l}\text { Distributed } \\
\text { fodder }\end{array}$ & \multicolumn{2}{l}{ Total quantity(g) } & $\begin{array}{l}\text { Ingestion } \\
\text { rate(\%) }\end{array}$ \\
\cline { 3 - 4 } & Served & Ingested & \\
\hline A & Sorghum Straw & 63000 & 34930 & 55,44 \\
B & Sorghum Straw & 59500 & 36530 & 61,39 \\
& C. procera & 3500 & 3500 & 100 \\
C & Sorghum Straw & 56000 & 33930 & 60,58 \\
& C. procera & 70000 & 6905 & 98,64 \\
\hline
\end{tabular}

Table 3 ADG of sheep by experimental groups

\begin{tabular}{|c|c|c|c|c|}
\hline \multirow{2}{*}{ Groups } & \multicolumn{2}{|l|}{ Periods } & \multirow{2}{*}{$\begin{array}{l}\text { Total weight } \\
\text { gain }(\mathrm{g})\end{array}$} & \multirow{2}{*}{ ADWG (g) } \\
\hline & $\mathbf{D}_{0}$ & $\mathbf{D}_{35}$ & & \\
\hline A & $13,4 \pm 2,0^{a}$ & $12,8 \pm 2,0 \mathrm{a}$ & $-640 \pm 260^{a}$ & $-18,2 \pm 7,4^{a}$ \\
\hline B & $13,3 \pm 3,2^{a}$ & $13,5 \pm 3,2 \mathrm{a}$ & $200 \pm 282^{b}$ & $5,7 \pm 8,0^{b}$ \\
\hline C & $|3,3 \pm 3,|^{a}$ & $13,4 \pm 3,0 \mathrm{a}$ & $40 \pm 384^{b}$ & $I, I \pm 10,9^{b}$ \\
\hline
\end{tabular}

a, b, c, Means with the same letters on the same column are not significantly different $(P<0.05)$

\section{Discussion}

Supplementation with forages rich in protein is often required to improve production in ruminant in farmers' areas where animal feed is based on the exploitation of natural pastures. The objective of our study is to improve this practice by exploiting the available natural resources such as Calotropis procera. The dry matter analysis of $C$. procera leaves showed a high percentage of dry matter $(93.20 \%)$, which is slightly lower than that $(94.6 \%)$ of Maroyi et al. ${ }^{9}$ and above $(84.65 \%)$ in Kanazoe ${ }^{10}$ during the rainy season in Burkina Faso. These differences could be explained by the periods and place of harvest that are probably not the same in our study.

During the study, the distribution of dried leaves of C. Procera did not affect the general behavior of animals in the two supplemented groups. Kanazoé ${ }^{10}$ and Fall et al. ${ }^{11}$ reported the same in Burkina Faso and Senegal respectively. This may be due to the action of drying which could have eliminated the toxicity of the plant because it is admitted that fresh leaves are toxic to ruminants. Analysis of the ingestion rate in the study shows that $C$. Procera is very popular and increases sorghum straw intake. Fall et al. ${ }^{11}$ showed that $C$. Procera leaves are more palatable and more digestible than pods and leaves of Faidherbia albida.

In our study, leaf supplementation of $C$. Procera positively influenced the intake rate of sorghum straw; the animals of the supplemented groups carried out an ingestion rate more than the control batch. This difference could be explained by the high percentage of nitrogen $(\mathrm{N})$ contained in C. Procera ${ }^{12}$ which increased digestibility ${ }^{11}$ and consequently, the consumption of the distributed ration. This finding corroborates the observations made by Swanson et al. ${ }^{13}$ that supplementation of poor fodder by food containing high protein and rich in carbohydrates creates favorable conditions in the rumen for the proliferation of microflora and increases their capacity to damage roughage. This suggests that the quantity of $C$. Procera distributed to animals would act as catalytic supplementation to improve the quantity consumed and digestibility of sorghum straw used to induce production as in the study. ${ }^{14}$ Indeed, supplemented sheep behaved in a different manner depending on the quantity of dry leaves of C. Procera distributed. The animals of group B (100g of $C$. Procera) achieved a weight gain greater than those of group C. (200g of C. Procera). However, the control group knew a decrease of weight, which was expected because the straw was of poor quality.

The quantity of $100 \mathrm{~g}$ of C. procera of group B induced the highest ingestion rate of sorghum straw and a higher weight gain compared to group C. This observation confirms the results of Kanazoé ${ }^{10}$ carried out in the rainy season in Burkina Faso. This leads us to think like Abbassi et al. ${ }^{15}$ that high consumption of $C$. procera has a detrimental effect on the deliberate ingestion of food due to the presence of toxic chemicals, including calotropin and calotropagenin contained in the latex, which have anti-palatability effects. It is probably this finding that led Maroyi et al. ${ }^{16}$ to dry the leaves of the plant to reduce the latex level from $162 \mathrm{mg} / \mathrm{g}$ to $2 \mathrm{mg} / \mathrm{g}$ and thus reduce toxicity. The ADWG results in our study are lower than those found in other studies of sheep supplementation. Kanazoe ${ }^{10}$ found an ADWG ranging from 70 to $81.42 \mathrm{~g}$ with the same forage of the plant distributed in the same proportions as our study. This difference of the results could be related to the season. Boukila et al. ${ }^{17}$ observed a weight loss of the control batch of $-10.25 \mathrm{~g}$ for animals receiving only Brachiaria ruziziensis against a GMQ of $32.75 \mathrm{~g}$ for animals supplemented with $800 \mathrm{~g}$ of fresh cassava leaves (Manihot esculenta).

\section{Conclusion}

The results of the study show that particular attention needs to be paid to the use of C. Procera in small ruminant farms in rural areas to improve their productivity. This can be achieved through a strategy of catalytic supplementation for optimum use of cereal straws available on family farms. Indeed, these straws are generally poor nutritive values during the hot dry season, where natural pasture is scarce and poor quality

\section{Acknowledgements}

The authors thank the International Atomic Energy Agency (IAEA) for the support of reagents and equipment at the Laboratory of Biology and Animal Health (LaBioSA) of INERA.

\section{Conflict of interest}

Authors declare that there is no conflict of interest.

\section{References}

1. Ministère de l'Agriculture, de 1'Hydraulique et des Ressources Halieutiques (MAHRH). Programme de spécialisation Régionale, Ouagadougou/Burkina Faso; 2008. 99p.

2. Ministère des Ressources Animales (MRA). Annuaire 2014 des statistiques de l'élevage. Programme d'appui au renforcement de la gestion des finances publiques et des statistiques (PAR-GS) 2013-2014; 2015. p. 177. 
3. Ministère des Ressources Animales (MRA). Plan d'Action et Programme d'Investissements du Sous-secteur de l'Elevage (PAPISE) 20102015. 2010. 75 p

4. Gnanda BI, Wereme/N'Diaye A, Sanon HO, et al. Rôle et place de la chèvre dans la vie des ménages du Sahel burkinabé. Revue Tropicultura. 2016;34(4):10-25.

5. Gnanda BI. Importance socio-économique de la chèvre du Sahel burkinabé et amélioration de sa productivité par l'alimentation. Thèse de Doctorat Unique en Développement Rural, option Système de Production Animale. Spécialité Nutrition et alimentation, Institut du développement rural (IDR), Université polytechnique de Bobo- Dioulasso (UPB), Burkina Faso. 2008. 180p.

6. Ministère des Ressources Animales et Halieutiques (MRAH). Plan National d'Adaptation (PNA) aux changements climatiques du sous-Secteur de l'Elevage. Document de Profil de Projets d'adaptation. Japon/ CONEDD/UNDP. Ouagadougou, Burkina Faso; 2013.76p.

7. Guinko S. Végétation de la Haute-Volta. Thèse de Doctorat, Université de Bordeaux III (France); 1984:394.

8. Association of Official Analytical Chemist. Official Method of Anaysis 15th ed. AOAC Washington DC; 1990

9. Maroyi A. Calotropis procera (Aiton) WT Aiton. In: Schmelzer GH, Gurib-Fakim A, editors. Prota 11(2). Medicinal plants/Plantes médicinales 2. PROTA, Wageningen, Pays Bas. Consulté le; 2012.

10. Kanazoé O. Effet de Différents niveaux de supplémentation des feuilles de Calotropis procera sur les performances de croissance et la charge parasitaire chez les ovins de race mossi en saison pluvieuse au Burkina Faso. Mémoire de fin cycle de la Licence en Productions Animales de l'Université Saint Thomas d'Aquin. Ouagadougou; 2016. 31p.
11. Fall ST, Guérin H.Sall C H et M'baye ND. Utilisation d'Acaciaalbida et de Calotropis procera pour améliorer les rations des petits ruminants au Sénegal - The use of d'Acaciaalbida and Calotropis procera for improving small ruminant diets in Senegal. LNE/RV, ISRA. 1987.

12. Millaiti M, Traore AS, Moleta R. Détermination de la composition physico-chimique des feuilles de Calotropis procera provenant de Ouagadougou (Burkina Faso) et de N'Djaména (Tchad). Revue du CAMES, Sciences et Médecine. 2003;2:87-92.

13. Swanson KC, Freetly C, Ferrel CL. Nitrgen balance in lambs fed low-quality brome hay and infused with differeng proportion of casein in the rumen and abomasum. J Anim Sci. 2004;82(2):502-507.

14. Agrodok. Les résidus de culture pour l'alimentation animale. Fondation Qgromisa et CTA, Wagenigen /Pays-Bas; 2015. 110p.

15. Abbassi K, AtayKadiril Q, Ghaout S. Biologie activity of Calotropis procera (Ait. R. Br) leaves on the desert locust (Shistoceragregaria, Forsk. Zool. Baetica. 2004;15:153-166.

16. Maroyi A. Calotropis procera (Aiton) WT Aiton. In: Schmelzer GH, Gurib-Fakim A, editors. Prota 11(2). Medicinal plants/Plantes médicinales 2. PROTA, Wageningen, Pays Bas ; 2012

17. Boukila B, Tendonkeng F, Lemoufouet J, et al. Effets de différents niveaux de supplémentation des feuilles fraîches de manioc (Manihotesculenta) sur les performances de croissance, la charge parasitaire et quelques caractéristiques du sang chez la chèvre naine de Guinée. Bull Anim Hlth Prod Afr. 2011;59:345-356. 